\title{
EFFECT OF POLLUTION ON THE WATER QUALITY OF THE GULF OF SUEZ
}

\section{Mohamed A. Hamed and Tarek O. Said}

National Institute of Oceanography and Fisheries, Aqaba and Suez Gulfs branch, Suez P.O. 182 Egypt

\section{(Received November 11, 1999)}

Key words: water quality, oil pollution, nutrients, chlorophyll, Suez Gulf

\section{ABSTRACT}

Water samples were collected from the Gulf of Suez during July, 1998. Nutrient salts (ammonia, nitrite, nitrate and phosphate) and chiorophyll- $a$ were measured spectrophotometrically, while the concentrations of dissolved hydrocarbon fractions were measured spectrofluorometrically. The results show that the maximum concentration of heavy petroleum fractions is $\sim 9.3 \mu \mathrm{g} / \mathrm{L}$ recorded at Ras Shukeir, where high oil fields activities are centered. Nutrient salts were relatively high at the northern part of the Gulf of Suez (Suez Bay). Their concentrations were $4.14,0.45,4.6$ and $1.04 \mu \mathrm{g}$ at./L for $\mathrm{NH}_{4}{ }^{+}, \mathrm{NO}_{2}{ }^{-}$, $\mathrm{NO}_{3}{ }^{-}$and $\mathrm{PO}_{4}{ }^{3-}$ respectively. Chlorophyll- $a$ and phytoplankton biomass were ranging between $0.12-2.54 \mathrm{mg} / \mathrm{m}^{3}$ and $9.0-190.5 \mu \mathrm{gC} / \mathrm{L}$ respectively. The present study revealed that the Suez Bay area can be considered as eutrophic region. This is related to sewage and/or industrial waste discharges along the western coast of the Bay. The rest of the Gulf area is considered as oligotrophic region. Also the results show that nitrogen is the limitng factor for phytoplankton growth in the Gulf of Suez.

\section{INTRODUCTION}

Nitrogen and phosphorus are the main limiting nutrients for primary production and also the main nutrients responsible for increasing 
eutrophication (Rast and Lee, 1978). Nutrients are considered critical besides water and carbon dioxide that are needed by plants in the synthesis of organic materials. Most of such elements are in the form of usable components (Stowe, 1979). Plankton, particularly phytoplankton have been used as indicators of water quality. Some species flourish in highly euotrophic water, while others are very sensitive to organic and/or chemical wastes. The species assemblage of phytoplankton and zooplankton also may be useful in assessing water quality. Because of their short life cycles, planktons respond quickly to environmental changes and hence their standing crop and species composition are more likely to indicate the quality of the water mass in which they are found. The value of phytoplankton in a water body forming the basal link in the food chain of fishes has been well recognized (Abd El-Rahman, 1993). Water quality criteria is not only intended to protect essential and significant life in water, as well as the direct users of water, but also to protect life that is dependent on water for its existence, or that may consume intentionally any edible portion of such life. Marine oil pollution is a problem of heavy burden to the recent aquatic life. It has been estimated that a quantity of 2.35 million tons of oil per year enter the marine environment from all sources (GESAMP, 1993). Of most paramount importance in this respect is the aromatic hydrocarbon fractions of petroleum. Clark (1986) stated that oil fractions are certainly toxic to a wide range of planktonic organisms. Specifically aromatic compounds are more effective than aliphatic ones. Very low concentration of petroleum hydrocarbons $<50 \mathrm{ng} / \mathrm{g}$ enhance photosynthesis while a progressive depression of photosynthesis in algal cultures occurs at higher concentrations. Oil pollution from oil fields, refineries and petrochemical industries is ranked as the most hazardous among pollutants added to the Gulf of Suez environment. The aim of this work is to determine the concentration levels of dissolved petroleum hydrocarbons, nutrient salts and chlorophyll-a in water of the Gulf of Suez. This can be of paramount importance in assessing the sources and the extent of pollution in this region, to put forward some recommendations, to save the whole environment in the area in clean conditions. 


\section{MATERIALS AND METHODS}

Sampling

One cruise was made on EL Yarmouk vessel along the Gulf of Suez extended from Adabiya (latitude of $30^{\circ} 26^{\circ} \mathrm{N}$ \& longitude of $32^{\circ}$ $33^{\circ} \mathrm{E}$ ) to Safaga (latitude of $27^{\circ} 15^{\circ} \mathrm{N} \&$ longitude of $34^{\circ} 10^{\circ} \mathrm{E}$ ) during July, 1998. Water samples were collected from 11 locations distributed along the Gulf of Suez at 2 depths; $1 \mathrm{~m}$ depth at the surface and at $10 \mathrm{~m}$ depth in the bottom, using acid washed PVC Niskin bottles, Fig. (1).

Apparatus and Equipment

- Spectrophotometer (Beckman, DU-6 UV/N single beam).

- Digital Spectrofluorometer (Sequoi-Turner Corporation, USA.), Model 450 with NB 360 for excitation filter and SC 415 for emission filter. Both filters are used for heavy petroleum fractions.

- Rotary evaporator, (Heidolph, Germany).

- Digital pH meter (Orion model 210).

- Salinometer (Yellow Springs Instrument Co. model 33).

Procedures

Dissolved Oxygen was determined by the Winkler method described in ROPME (1989). Nutrient salts viz.: ammonia, nitrite, nitrate and inorganic phosphorus were determined according to Strickland and Parsons (1975). Chlorophyll- $a$ was determined spectrophotometrically after acetone extraction of pigments from phytoplankton samples retained on the membrane filters according to Strickland and Parsons (1975). For hydrocarbon measurement, sampling and experimental procedures were made following the methods described by Parson et al., (1985). Extraction of dissolved/dispersed petroleum hydrocarbons was carried out using methylene chloride. The extracts were cleaned using silica gel column to remove polar organic and the measured value (using the 
specrtrofluorometric technique after elution with hexane) was attributed to petroleum hydrocarbons only.

\section{RESULTS AND DISCUSSION \\ Environmental characteristics (Table 1)}

It was noticed that the temperature values of the Gulf of Suez increase northward, due to the effect of the ambient air. The $\mathrm{pH}$ is an important factor in the chemical and biological systems of natural waters. It is greatly affected by the photosynthetic activity of aquatic flora, temperature and the amount of organic constituents (Hutchinson, 1974). Normal $\mathrm{pH}$ value in seawater is between 8.0-8.2 at the surface, decreasing to 7.7-7.8 with increasing depths (Capurro, 1970). In the Gulf of Suez, $\mathrm{pH}$ values were found to increase southwards, where the maximum $\mathrm{pH}$ of 8.25 was recorded at Ras Shukeir (far from industrial or sewage waste water) while a minimum $\mathrm{pH}$ of 8.08 was recorded at Adabiya Port which is affected by the disposal of mainly acidic sewage and industrial effluents, in addition to oil refineries effluents distributed in the Suez Bay area.

The results indicate that the salinity of the Gulf of Suez was increasing from south to north. This accords with Morcos (1970), who stated that high salinity of the Gulf of Suez particularly at its northern part is attributed to the inflence of high saline water of the Suez Canal.

Also, low level of dissolved oxygen (DO) was observed at Adabiya (the northern part of the Gulf), indicating consumption of DO for bacterial oxidation of organic pollutants and or domestic wastes from dwellings of the area. The high concentration of DO at Safaga may reflect the importance of active mixing and gas exchange in this area.

A BOD of $1 \mathrm{ppm}$ is a characteristic of nearly pure water, as this value reaches $5 \mathrm{ppm}$ it is considered as doubtful pure water (Anon, 1975). Comparing this result of BOD presented in Table 2 with the tolerable 
level for pure water, slightly higher level was particularly reported at the northern part of the Gulf, indicating the presence of perceptible load of domestic wastes discharging into this region.

\section{Nutrients and Chlorophyll-a}

Table (2) represents the distribution of nutrients along the Gulf of Suez during 1998. It is clear that the nutrient salts concentrations increase gradually from the south to the north and reach to the maximum at location 1(Adabiya). The concentrations of ammonia, nitrite, nitrate and phosphate were $4.14,0.45,4.6$ and $1.04 \mu \mathrm{g}$ at./L respectively at Adabiya region. Such high concentrations are indicators of the presence of pollutants of high activity viz.: sewage discharge, industrial effluents and oil refineries concentrated at the northern part of the Gulf (Suez Bay).

Comparing the present data of nutrients with the previous records in the Gulf of Suez and other regions indicates that they are comparable to other records (Table 3). Also, it is obvious that the area of investigation can be divided into two regions, Suez Bay region as an eutrophic water and the part of the Gulf as going southward to Safaga, which is considered as an oligotrophic water. This conforms with Abd El Rahman (1993) who stated that the Suez Bay is regarded among the eutrophic regions when considering the magnitude of the standing crop of zooplankton. This is particularly true at the inshore stations due to the high load of sewage and industrial wastes discharged into the area. Such pollution can obviously lead to a gradual deterioration of the water quality in the Bay. Accordingly, it is recommended that this wastewater should be treated to improve its quality before being discharged into the Bay.

Generally, the calculated ratio for N:P (2.29:1) was lesser than that given by Redfield ratio (16:1) (Redfield et al., 1963). Thus nitrogen was the limiting factor for phytoplankton growth in the study area. 
Table (4) indicates that chlorophyll-a was increased from south to the north, reaching its maximum value at Adabiya, probably due to sewage discharge and industrial effluents at such region. It is obvious that high transparency of $5.00 \mathrm{~m}$ was recorded at Safaga, indicating low pollution level status at such location while the lowest transparency of $2 \mathrm{~m}$ was recorded at Adabiya with high industrial activities. In general transparency gives an indication of the growth of free floating planktonic organisms (phytoplankton and zooplankton), whose relation is negative $(-0.866)$. On the other hand, the growth of planktonic organisms is related to the increase of nutrient concentrations. This means that the relation between transparency and nutrients is also reversible.

\section{Oil pollution}

According to Figure 2, the area of investigation can be regionally divided into 4 sectors. Sector $A$ lies at the northern part of the Gulf (Suez Bay) and had concentrations of 4.86 and $4.58 \mu \mathrm{g} / \mathrm{L}$. Sector B (locations of Ain Sukhna and Ras Sudr) with mean concentrations of 3.31 and $3.22 \mu \mathrm{g} / \mathrm{L}$. Sector C, in the middel part of the Gulf (locations of Zafarana, Abu Zenima, Ras Gharib and Ras Shukeir) had mean concentrations of 6.14 and $3.56 \mu \mathrm{g} /$. And Sector D, at the Red Sea proper (Gubal, Giftun, Safaga and port of Safaga) had mean concentrations of 1.99 and $1.11 \mu \mathrm{g} / \mathrm{L}$ for surface and bottom water respectively. It is obvious that the higher level of oil was recorded at the middle part of the Gulf especially at location 7 with $9.3 \mu \mathrm{g} / \mathrm{L}$, where this area is affected by high oil field activities distributed at Ras Shukeir. The lower value of $1.18 \mu \mathrm{g} / \mathrm{L}$ was recorded at Gubal far from oil fields activity. So, the water of the Red Sea proper does not greatly interfere with the water quality of the Gulf of Suez. This is also evident by the limited concentration of dissolved hydrocarbons $(\sim 1.18 \mu \mathrm{g} / \mathrm{L})$ at the strait of Gubal that is not affected by polluting source at Safaga Port (Red Sea proper) with a concentration of $2.67 \mu \mathrm{g} / \mathrm{L}$.

However, in the Gulf of Suez northerly winds prevail most of the year (Morcos, 1970). Such winds enhance the movement of contaminants at location 
7 (Ras Shukeir) upward to location 4 (Zafarana).Meanwhile, the anticlockwise circulation of water of the northern part of the Gulf of Suez brings the petroleum contaminants to location 3 (Ras Sudr) (Meshal, 1970).

Moreover, there is a negative correlation $(r=-0.759$ at the surface and $r=-0.431$ in the bottom) between the temperature and the dissolved hydrocarbons along the Gulf of Suez. The effect of DO on the levels of dissolved hydrocarbon fractions is illustrated in Fig. 3. where, a higher negative correlation exists at the surface $(r=-0.700)$ than in the bottom $(r=0.253)$. This is in accordance with Mille and Bertrand (1988), which stated that the hydrocarbon degradation occurred markedly at $8 \mathrm{mg} \mathrm{O}_{2} / \mathrm{L}$, and becomes slower (by 2 to 3 times) at 2-3 $\mathrm{mg} \mathrm{O} / \mathrm{L}$ while no degradation was detected at $0.2-0.3 \mathrm{mg} \mathrm{O} / \mathrm{L}$. Thus we can conclude that the state of oil pollution in the Gulf of Suez might affect on the DO levels necessary for the biological and chemical processes taking part in the marine environment of the area. In other wards the water quality of the Gulf will be seriously affected.

\section{CONCLUSION}

The present investigation reveals that high concentration of dissolved hydrocarbons is present of the water body of the Gulf of Suez; particularly oil fields, at Ras Shukeir with concentration up to $9.3 \mu \mathrm{g} / \mathrm{L}$. Also, the Gulf of Suez can be regionally divided into two regions. The Suez Bay area which regarded among the eutrophic region (high productivity). This is related to sewage and/or industrial activities distributed along the western coast of the Bay. Needless to say that such kind of pollution will obviously lead to a gradual deterioration of the water quality of the Bay. The rest area of the Gulf is considered as oilgotrophic area (low productivity) as a result of the serious state of oil pollution. It was also found that nitrogen was the limiting factor for phytoplankton growth in the Gulf of Suez. 


\section{REFERENCES}

Abd EL-Rahman N. S. (1993). "Ecological studies on the distribution of zooplankton communities in the northern part of the Suez Gulf 'Suez Bay"'. M. Sc. Thesis, Faculty of Science, Suez Canal University, $316 \mathrm{pp}$.

Aboul-Kassim T. A. (1987). "Cycles of carbon, nitrogen and phosphorus in the marine environment in Alexandria region". M. Sc. Thesis, Fac. Sci., Alex. University.

Anon (1975). "Environmental central and Public Health, Water Analysis,

Standards and Treatment, Eyre and Spottiswoode Ltd., ECPH, 131.

Behairy K. A. and Saady M. A. (1984). Tethy, 11, 111.

Capurro L. R. (1970). "Oceanography for practicing engineers". Barnea and Noble Inc., New York.

Clark R. B. (1986). "Marine Pollution". Clarendon Press, Oxford.

Fahmy M. A. (1997). "Hydrochemistry and nutrients of Abu-Qir Bay during summer, 1995. Bull. Fac. Sci., Alex. Univ., 37, 2, 171-186.

Farah O. M. (1991). "Symposium of marine chemistry in the Arab region". Suez, Egypt. April, 21-23.

Franco P. (1983). "Fattori influent sulla productivita primaria dell Adriatico settentrionala". Proc. Int. Conf., Problems of the Adriatic Sea Trieste, pp 155-174.

GESAMP (IMO/FAO/UNESCO/WHO/LAEA/UN/UNEP); Joint group of experts on the scientific aspects of marine (1993). "Impact of oil and released chemicals and wastes on the marine environment". Reports and studies No. 50, International Maritime Organization, London.

Hamed M. A. (1998). "Environmental studies on AL Khor area, Suez, Egypt". J. Environmental Science. Faculty of Science, Mansoura University, . 15, 181-201pp. 
Hamed M. A. (1996). "Determination of some microelements in the aquatic system and their relation to the efficiency of marine life". Ph. D. Thesis. Faculty of Science, Mansoura University, 120pp.

Hamed M. A. (1992). "Sea water quality at the northern part of the Gulf of Suez and the nearby area of the Suez Canal". M. Sc. Thesis. Facuity of Science, Mansoura University, 81pp.

Hutchinson G. E. (1974). "A treatise on Limnology". Limnology. Willey, New York, 1, 1015-1022.

Meshal A. M. (1970). "Water pollution in the Suez Bay". Bull. Inst. Ocean.\& Fisheries, 9: 463-470.

Mille G. and Bertrand J. (1988). "Effects of Oxygen on hydrocarbons degradation studies in vitro in surficial sediments". Estuarine, Coastal and Shell Science, 27: 283.

Mohamed A. A. (1994). "Study of iodine cycle in Suez Bay". M. Sc. Thesis, Faculty of Science, Helwan University, Egypt, 90pp.

Morcos S. A. (1970). "The tidal currents in the southern part of Suez Canal". Gen. Ass. of Helsinki, Finland, 5I: 307-312.

Parsons T. R., Maita Y. and Malli G. M. (1985). "Determination of petroleum hydrocarbons". A Manual of chemical and Biological Method for seawater Analysis. Pergamon Press, Oxford.

Rast W. and Lee G. (1978). "Summary analysis of the north American/ U.S. Protein/ OECD". Eutrophication Project, nutrient loading-Lake response relationship and trophic state. Ecol. Res., EPA-600/3-78008, U.S. EPA, Carvallis, Oregon, U.S.A., 478.

Regional Organization for the Protection of the Marine Environment (ROPME) (1983). "Manual of Oceanographic observation and pollutant Analysis Methods, Kuwait, 300pp. 
Redfield A. C., Katchum B. H. and Richard S. A., (1963). "The influence of organism on the composition of seawater". In: The Sea, Vol. 2, M.N. Hill (Ed.) John Wiley and Sons, New York, 26-77pp.

Skrivanic V. and Strin J. (1982). "Basic physical, chemical and biological data Reports". R. V. "A Mohorov ICIC" Adriatic cruises, 1974-76. Hydrographic Inst. \& Yugoslav Navy-split, 175pp.

Stowe K. S. (1979). "Ocean Science". John Wiley (Eds.), Los Angeles.

Strickland J. D. and Parsons T. R. (1975). "A Practical handbook of seawater analysis". Fish Res. Bull. Canada, 167: 310pp.

Tayel F. F., Fahmy M. A. and Sheriadah M. A. (1997). "Studies on physicochemical characteristics of the EL Mex Bay and new Dekhaila Harbour waters of Alexandria". Bull. Nat. Inst. Ocean.\& Fisheries, ARE, 22: 1-18. 
Table 1. Hydrographical characteristics of seawater along the Gulf of Suez during July, 1998

\begin{tabular}{|l|c|c|c|c|c|c|c|c|}
\hline \multirow{1}{*}{$\begin{array}{c}\text { Parameter } \\
\text { Location }\end{array}$} & \multicolumn{2}{|c|}{$\begin{array}{c}\text { Temp. } \\
{ }^{\circ} \mathrm{C}\end{array}$} & \multicolumn{2}{c|}{$\mathrm{PH}$} & \multicolumn{2}{c|}{$\begin{array}{c}\text { Salinity } \\
\text { \%o }\end{array}$} & \multicolumn{2}{c|}{$\begin{array}{c}\text { DO } \\
\text { (mgO,/L) }\end{array}$} \\
\cline { 2 - 8 } & $\mathrm{S}$ & $\mathrm{B}$ & $\mathrm{S}$ & $\mathrm{B}$ & $\mathrm{S}$ & $\mathrm{B}$ & $\mathrm{S}$ & $\mathrm{B}$ \\
\hline 1-Adabiya & 28.25 & 28.00 & 8.08 & 8.11 & 42.13 & 42.29 & 4.98 & 4.87 \\
2-Ain Sukhna & 28.00 & 27.80 & 8.13 & 8.15 & 41.77 & 41.71 & 5.37 & 5.20 \\
3-Ras Sudr & 27.90 & 27.60 & 8.13 & 8.18 & 41.84 & 42.03 & 5.41 & 5.24 \\
4-Zafarana & 27.70 & 27.40 & 8.15 & 8.18 & 41.50 & 41.78 & 5.41 & 5.20 \\
5-Abu Zenima & 27.80 & 27.30 & 8.16 & 8.18 & 41.18 & 41.27 & 5.49 & 5.41 \\
6-Ras Gharib & 27.50 & 27.40 & 8.15 & 8.20 & 41.52 & 41.56 & 5.64 & 5.47 \\
7-Ras Shukeir & 27.50 & 27.20 & 8.25 & 8.22 & 40.59 & 40.87 & 6.04 & 5.95 \\
8-Gubal & 27.60 & 27.30 & 8.18 & 8.20 & 40.27 & 40.41 & 5.96 & 5.84 \\
9-Giftun & 27.60 & 27.30 & 8.18 & 8.24 & 40.17 & 40.43 & 6.15 & 5.98 \\
10-Safaga & 27.50 & 27.25 & 8.20 & 8.22 & 40.11 & 40.24 & 6.32 & 6.22 \\
11-Port of Safaga & 27.40 & 27.10 & 8.21 & 8.25 & 40.11 & 40.24 & 6.29 & 6.22 \\
\hline
\end{tabular}

$\mathrm{S}=$ surface $\& \mathrm{~B}=$ bottom

Table 2. Nutrient saits and BOD of seawater along the Gulf of Suez during July, 1998

\begin{tabular}{|l|c|c|c|c|c|c|c|c|c|c|}
\hline Parameter & \multicolumn{2}{|c|}{$\begin{array}{c}\mathrm{BOD} \\
\left(\mathrm{mgO}_{2} / \mathrm{L}\right)\end{array}$} & \multicolumn{2}{c|}{$\begin{array}{c}\mathrm{NH}_{3} \\
(\mu \mathrm{g} \text { at./L) }\end{array}$} & \multicolumn{2}{c|}{$\begin{array}{c}\mathrm{NO}_{2} \\
(\mu \mathrm{g} \text { at./L) }\end{array}$} & \multicolumn{2}{c|}{$\begin{array}{c}\mathrm{NO}_{3} \\
(\mu \mathrm{g} \text { at./L) }\end{array}$} & \multicolumn{2}{c|}{$\begin{array}{c}\mathrm{PO} 4 \\
(\mu \mathrm{g} \text { at./L) }\end{array}$} \\
\hline Location & $\mathrm{S}$ & $\mathrm{B}$ & $\mathrm{S}$ & $\mathrm{B}$ & $\mathrm{S}$ & $\mathrm{B}$ & $\mathrm{S}$ & $\mathrm{B}$ & $\mathrm{S}$ & $\mathrm{B}$ \\
\hline 1-Adabiya & 3.61 & 2.74 & 4.14 & 3.16 & 0.45 & 0.32 & 4.60 & 3.56 & 1.04 & 0.74 \\
2-Ain Sukhna & 2.14 & 1.75 & 2.18 & 1.75 & 0.30 & 0.25 & 1.66 & 1.81 & 0.56 & 0.61 \\
3-Ras Sudr & 0.98 & 1.04 & 1.11 & 1.66 & 0.17 & 0.20 & 0.84 & 1.05 & 0.45 & 0.51 \\
4-Zafarana & 2.36 & 1.88 & 1.36 & 1.65 & 0.22 & 0.26 & 1.78 & 1.57 & 0.50 & 0.59 \\
5-Abu Zenima & 1.04 & 0.83 & 0.93 & 1.29 & 0.13 & 0.19 & 1.53 & 1.32 & 0.47 & 0.38 \\
6-Ras Gharib & 1.56 & 1.42 & 1.29 & 1.25 & 0.22 & 0.24 & 2.66 & 1.48 & 0.43 & 0.40 \\
7-Ras Shukeir & 1.92 & 1.78 & 0.79 & 1.26 & 0.15 & 0.19 & 0.58 & 0.72 & 0.39 & 0.60 \\
8-Gubal & 1.81 & 1.20 & 0.28 & 0.62 & 0.07 & 0.11 & 0.95 & 1.09 & 0.25 & 0.32 \\
9-Giftun & 0.99 & 1.16 & 0.22 & 0.36 & 0.07 & 0.09 & 0.48 & 0.63 & 0.09 & 0.12 \\
10-Safaga & 0.89 & 1.05 & 0.18 & 0.40 & 0.10 & 0.12 & 0.53 & 0.58 & 0.08 & 0.13 \\
11-Port of Safaga & 1.12 & 0.99 & 0.18 & 0.47 & 0.08 & 0.13 & 0.52 & 0.63 & 0.09 & 0.16 \\
\hline
\end{tabular}

$\mathrm{S}=$ surface \& $\mathrm{B}=$ bottom 
Table 3. Nutrient salts concentrations ( $\mu$ gat./L) of seawater in the present study compared with other regions

\begin{tabular}{|c|c|c|c|c|c|}
\hline Parameter & $\mathrm{NH}_{3}-\mathrm{N}$ & $\mathrm{NO}_{2}-\mathrm{N}$ & $\mathrm{NO}_{3}-\mathrm{N}$ & $\mathrm{PO}_{4}-\mathrm{P}$ & References \\
\hline Gulf of Suez & $0.18-4.14$ & $\begin{array}{l}0.07- \\
0.45\end{array}$ & $0.48-4.6$ & $\begin{array}{l}0.08- \\
1.04\end{array}$ & Present study \\
\hline Al Khor, Suez & 3.54 & 0.38 & 2.06 & 0.62 & Hamed, 1998 \\
\hline -Gulf of Suez & 1.54 & 0.20 & 0.52 & 0.47 & Hamed, 1996 \\
\hline -Suez Canal & 2.44 & 0.59 & 2.03 & 0.81 & «، \\
\hline -Suez Bay & 3.25 & 0.49 & 1.48 & 0.85 & Hamed, 1992 \\
\hline -Suez Bay & 8.86 & 0.33 & 3.42 & 0.45 & Mohamed, 1994 \\
\hline $\begin{array}{l}\text {-Red Sea } \\
\text { *Jeddah }\end{array}$ & -. & 0.28 & 9.69 & . & Behairy and Saady, 1984 \\
\hline $\begin{array}{l}\text { "Dongonab Bay } \\
\text {-Mediterranean }\end{array}$ & -. & .- & $4.9-7.2$ & $0.3-1.5$ & Farah, 1991 \\
\hline $\begin{array}{l}{ }^{*} \text { Abu Qir Bay } \\
{ }^{*} \text { Eastern harbour of }\end{array}$ & 1.23 & 0.07 & 0.88 & 0.58 & Fahmy, 1997 \\
\hline $\begin{array}{l}\text { Aleandria } \\
\text { EL Mex Bay }\end{array}$ & $\begin{array}{c}3.16 \\
20.38\end{array}$ & $\begin{array}{l}0.95 \\
0.48\end{array}$ & $\begin{array}{l}6.79 \\
1.87\end{array}$ & $\begin{array}{l}0.56 \\
1.62\end{array}$ & $\begin{array}{l}\text { Aboul Kassim, } 1987 \\
\text { Tavel et al..1997 }\end{array}$ \\
\hline Oligotrophic level & 0.5 & 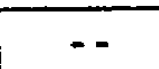 & 0.5 & 0.05 & Skrivanic and Strin, 1982 \\
\hline Eutrophic level & 2.02 & .. & 4.0 & & Franco, 1983 \\
\hline
\end{tabular}

Table 4. Chlorophyll-a, phytoplankton biomass and transparency measurements along the area of investigation during July, 1998

\begin{tabular}{|c|c|c|c|c|c|}
\hline \multirow{2}{*}{$\begin{array}{c}\text { Parameter } \\
\text { Location }\end{array}$} & \multirow{2}{*}{$\begin{array}{c}\text { Transparenc } \\
\mathbf{y} \\
(\mathrm{m})\end{array}$} & \multicolumn{2}{|c|}{$\begin{array}{l}\text { Chlorophyll-a } \\
\text { (mg/cm3) }\end{array}$} & \multicolumn{2}{|c|}{$\begin{array}{l}\text { Phytoplankton biomas } \\
(\mu \mathrm{gC} / \mathrm{L})\end{array}$} \\
\hline & & $\mathbf{S}$ & B & $\mathrm{S}$ & B \\
\hline 1-Adabiya & 2.00 & 2.54 & 1.68 & 190.5 & 126.00 \\
\hline 2-Ain Sukhna & 2.80 & 0.99 & 1.05 & 74.25 & 78.75 \\
\hline 3-Ras Sudr & 4.30 & 0.40 & 0.26 & 30.00 & 19.50 \\
\hline 4-Zafarana & 2.50 & 0.90 & 0.69 & 67.00 & 51.75 \\
\hline 5-Abu Zenima & 3.25 & 1.06 & 0.79 & 79.50 & 59.25 \\
\hline 6-Ras Gharib & 3.00 & 0.99 & 0.79 & 74.25 & 59.25 \\
\hline 7-Ras Shukeir & 3.50 & 0.88 & 0.46 & 66.00 & 34.50 \\
\hline 8-Gubal & 4.30 & 0.36 & 0.25 & 27.00 & 18.75 \\
\hline 9-Giftun & 4.50 & 0.17 & 0.25 & 12.75 & 18.75 \\
\hline 10-Safaga & 5.00 & 0.12 & 0.09 & 9.00 & 6.75 \\
\hline 11-Port of Safaga & 4.00 & 0.15 & 0.13 & 11.25 & 9.75 \\
\hline
\end{tabular}

$S=$ surface \& $B=$ bottom 


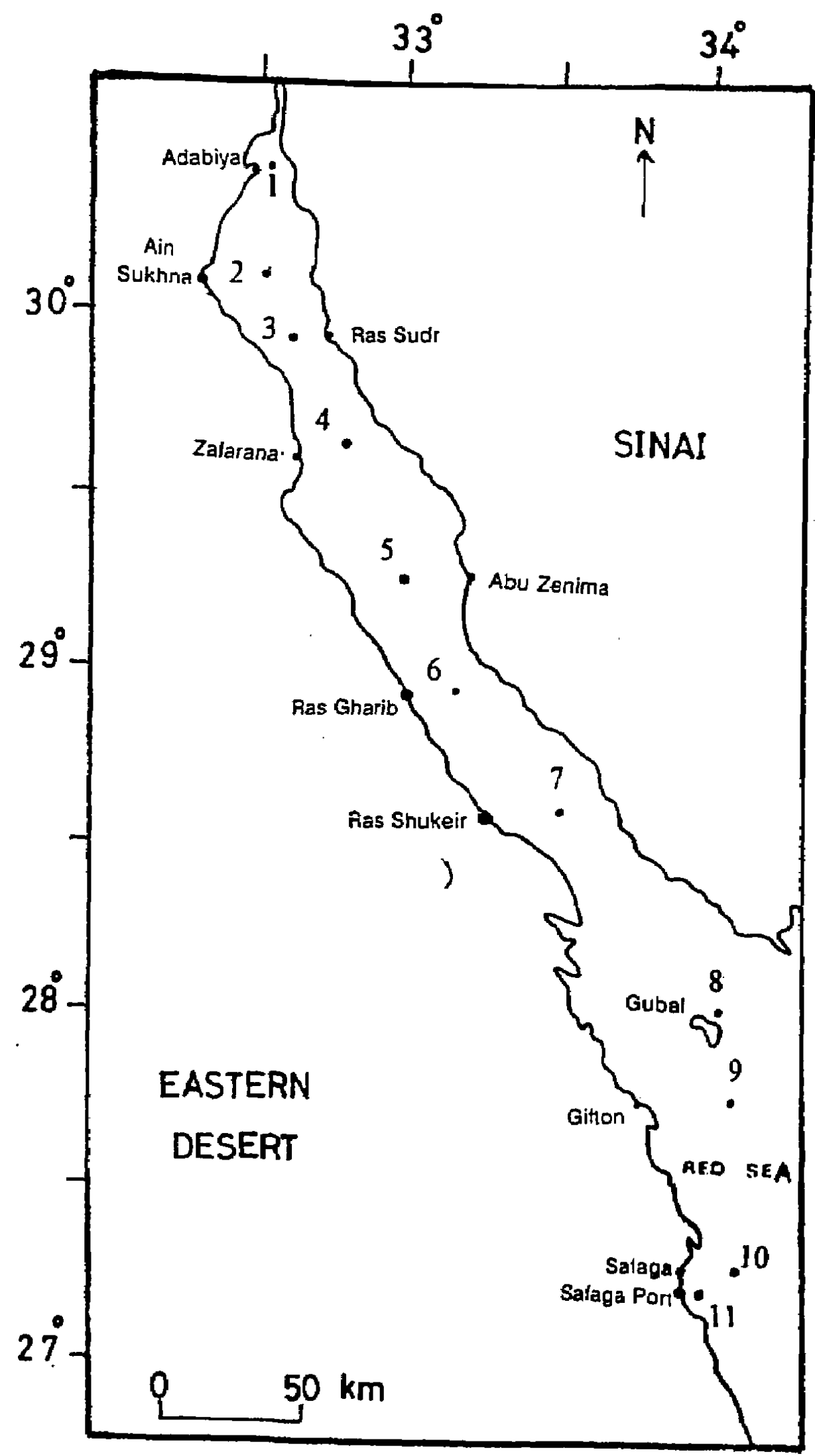

Fig. (1) Sampling locations collected from the Gulf of Suez during July, 19981)Adabiya, (2)Ain Sukhna, (3)Ras Sudr, (4)Zafarana, (5)Abu Zenima, (6)Res Gharib, (7)Ras Shukeir, (8)Gubal, (9)Giftun, (10)Safaga and (11)Port of Safige. 


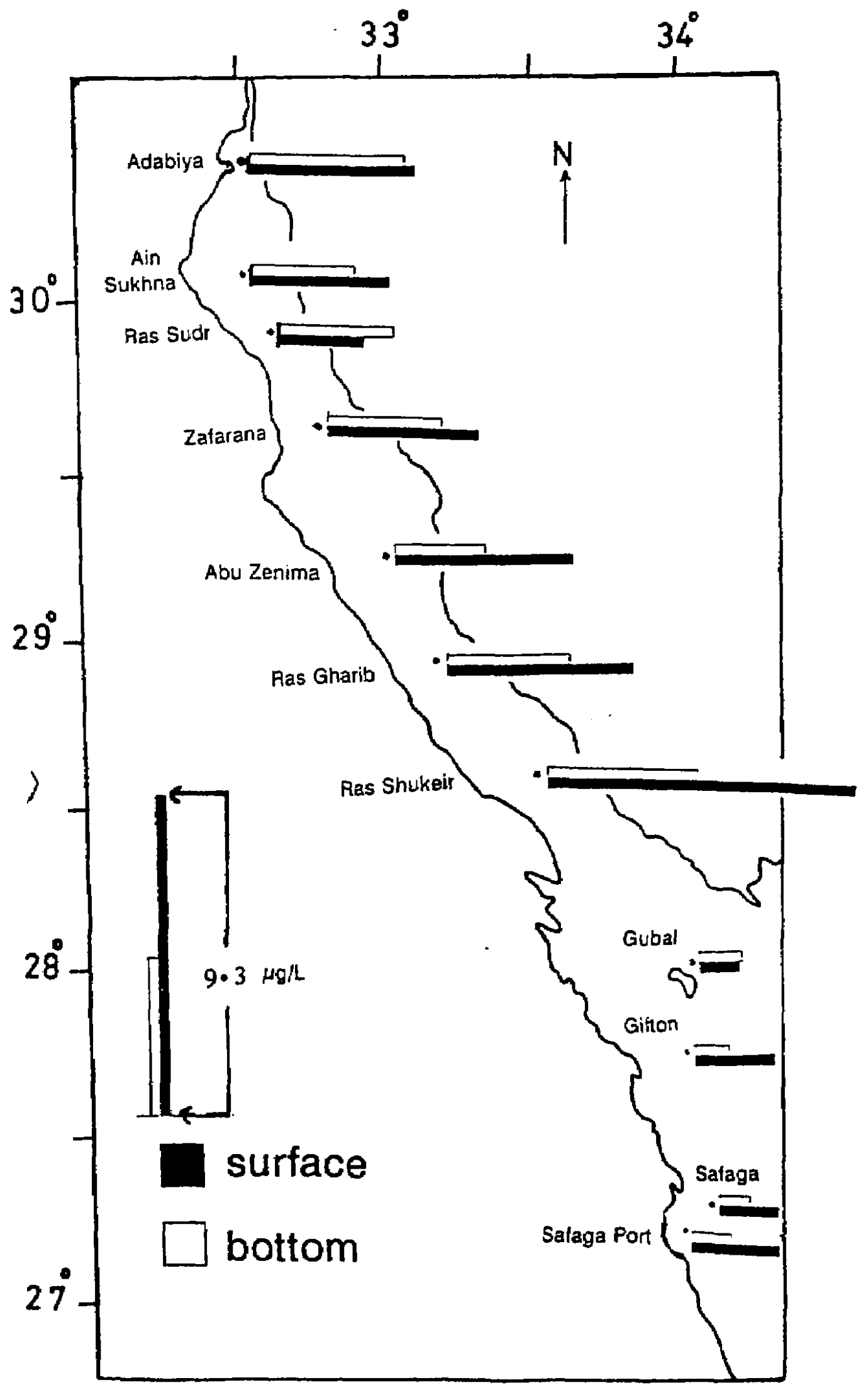

Fig. (2) Surface and bottom distribution of petroleum hydrocarbon concentrations long the Gulf of Suez during July, 1998. 


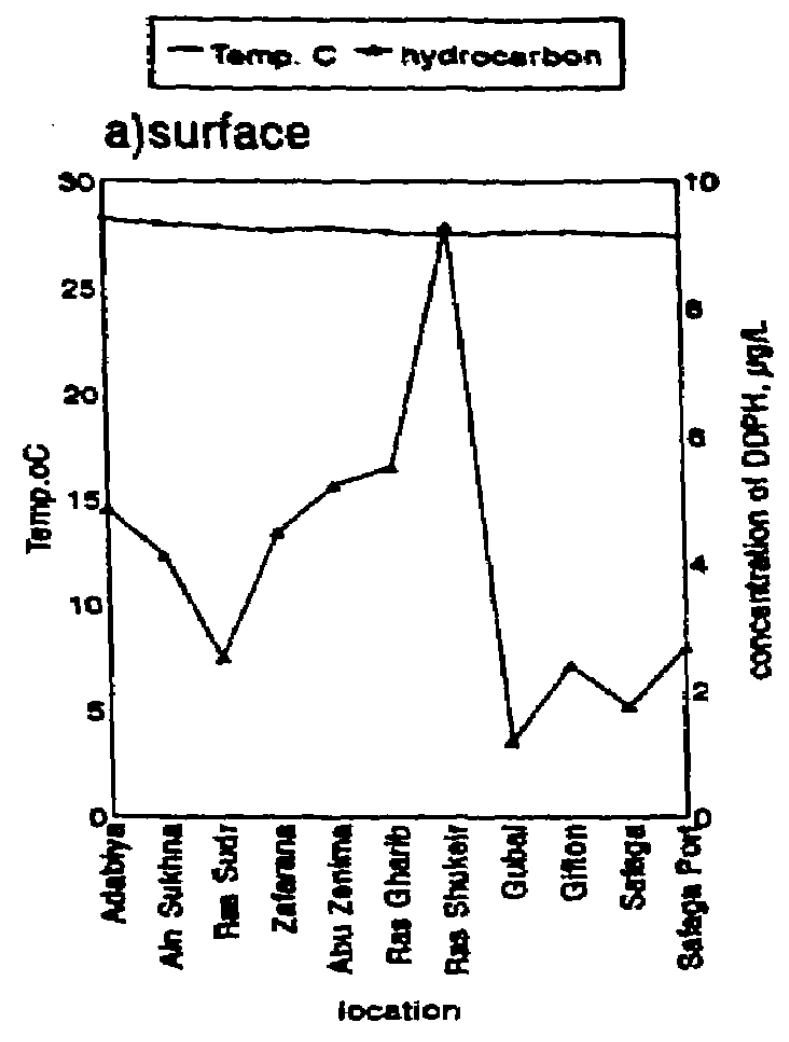

b)bottom

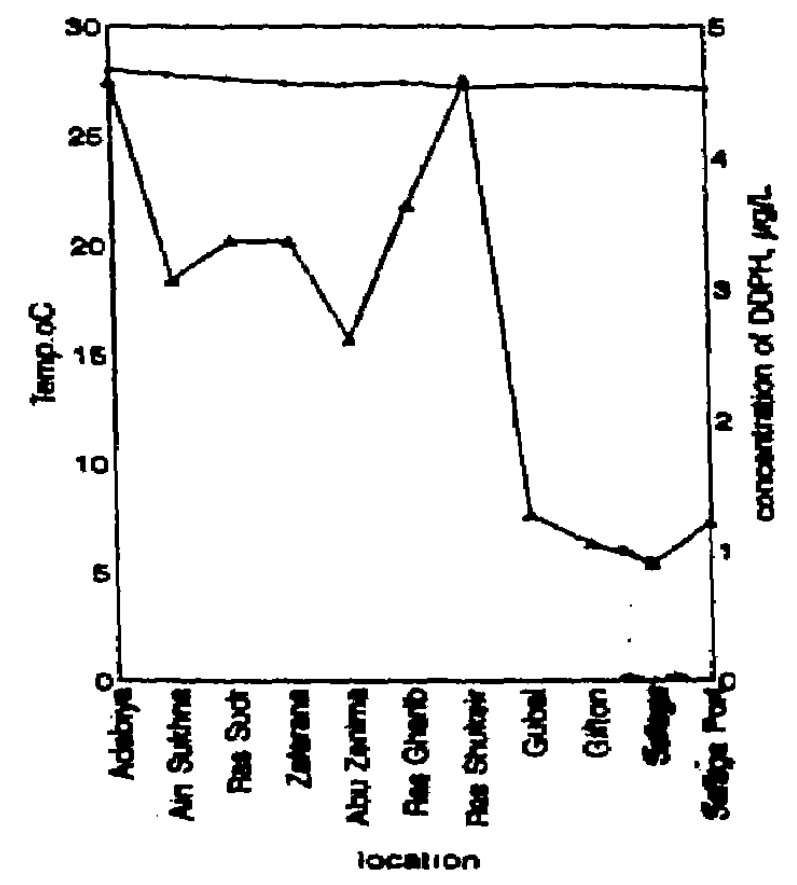

Fig. (3) The eflect of temperature on hydrocarbon degradation along the Gult of Suez during July, 1908 

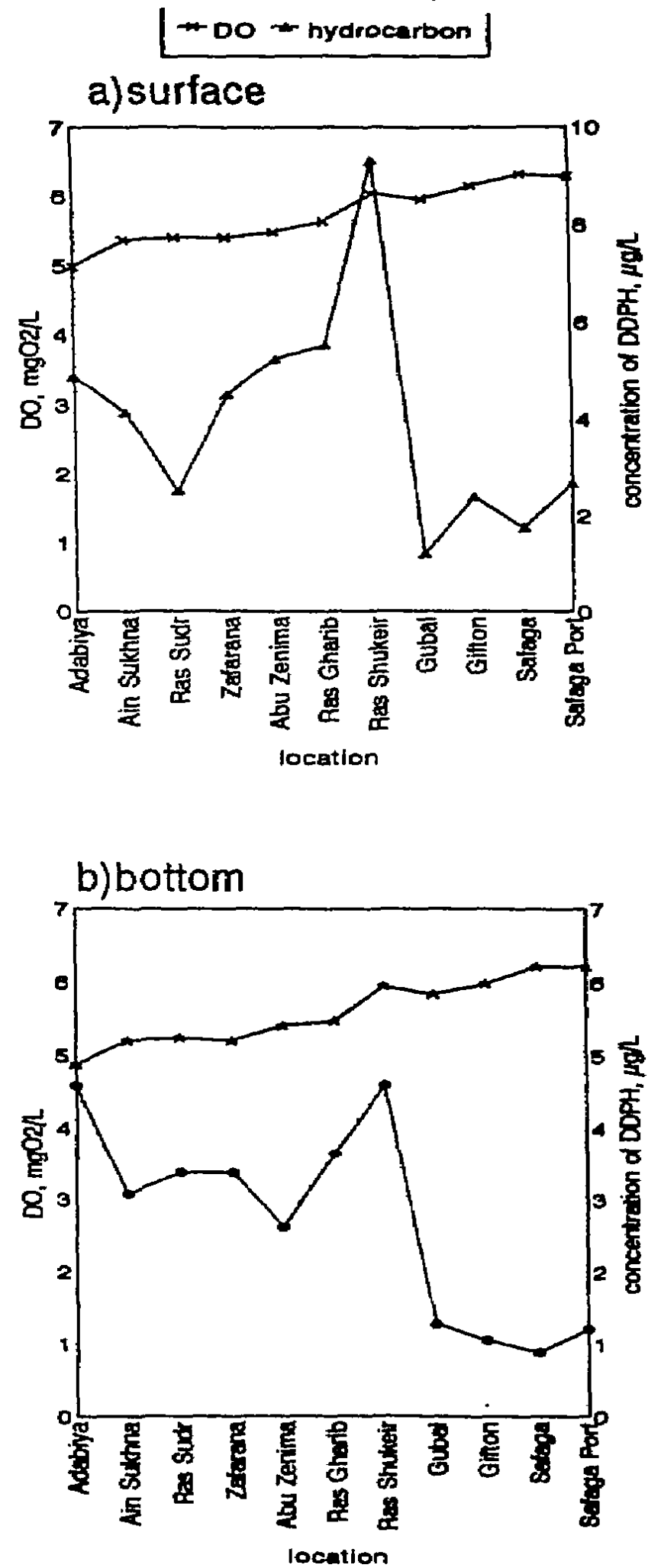

Fig. (4) The effect of DO on hydrocarbon degradation along the Gulf of Suez during July, 1998 